\title{
The Role of Non-Governmental Organization as a Civil Society in Corruption Supervision
}

\author{
Sri Rahayu ${ }^{1, *}$ Cecep Darmawan ${ }^{2}$ \\ ${ }^{1,2}$ Universitas Pendidikan Indonesia \\ "Corresponding author.Email: srirahayu01@upi.edu
}

\begin{abstract}
The case of corruption in Indonesia has become a very crucial problem, which threatens various sectors of life, one of which is in government. Various efforts have been made by the government, including the establishment of the Corruption Eradication Commission (KPK). However, it is not enough to establish the institution, but the support of various elements is needed. Such as the Non-Governmental Organization which is a forum for expressing public opinions and thoughts and has a role in increasing active community participation in national development. And civil society is a group of people formed as an organization that has the power to balance the government and has distinctive characteristics, namely volunteerism, self-sufficiency, and self-reliance. This study examines the role of Non-Governmental Organizations as civil society in efforts to control corruption. The method used in this research is a literature study. The results of the study indicate that with the volunteerism of the Non-Governmental Organization in National development, it can be said that the Non-Governmental Organization is a civil society. Which has a role as a forum for the community to convey their aspirations to the government. So it can be said that the Non-Governmental Organization as an organization representing civil society, becomes very strategic as a liaison between the community and government institutions.
\end{abstract}

Keywords: Civil Society, Corruption, Non-Governmental Organization.

\section{INTRODUCTION}

Every year corruption cases in Indonesia are still increasing and have become a very crucial problem. The losses incurred are certainly not small, the large number of corruption cases in Indonesia is caused by several factors including the lack of strict law enforcement, both from law enforcement officers and related institutions. Sometimes law enforcement officers or related institutions are also involved in the corruption, so eradicating corruption cases must be the government's priority in policymaking. Meanwhile, according to the results of research conducted by Science Magazine in 2019 with the title of Research on Honesty in the World Society which was carried out in 355 cities in 40 countries in the world, Indonesia is ranked 33 out of 40 countries. The honesty of the people of a nation determines the quality of its nation, as evidenced by a survey conducted by the Transparency International institution that Indonesia ranks third in Asia as the most corrupt country. Several programs have been established to tackle corruption in Indonesia, including the establishment of a state institution or agency, namely the Corruption Eradication Commission (KPK) which is given special authority by the Government.
The recapitulation of corruption cases conducted by the Corruption Eradication Commission (KPK) is divided into five categories. Namely Corruption by Institution, Type of Case, Profession / Position, Inkrach Case, and by region. It can be seen from the data from the Corruption Eradication Commission (KPK) that there are statistics on corruption cases every year in Indonesia, according to case data from 2019 to May 8, 2021, which are as follows:

Table 1. Corruption Case Enforcement Statistics Statistik

\begin{tabular}{|l|c|c|c|c|}
\hline Prosecution & $\mathbf{2 0 1 9}$ & $\mathbf{2 0 2 0}$ & $\mathbf{2 0 2 1}$ & Amount \\
\hline Research & 142 & 111 & 41 & $\mathbf{2 9 4}$ \\
\hline Investigation & 145 & 91 & 22 & $\mathbf{2 5 8}$ \\
\hline Prosecution & 153 & 75 & 34 & $\mathbf{2 6 2}$ \\
\hline Inkracht & 142 & 92 & 16 & $\mathbf{2 5 0}$ \\
\hline Execution & 136 & 108 & 18 & $\mathbf{2 6 2}$ \\
\hline \multicolumn{6}{|c|}{ Total } & $\mathbf{7 1 8}$ & $\mathbf{4 4 7}$ & $\mathbf{1 3 1}$ & $\mathbf{1 3 2 6}$ \\
\hline
\end{tabular}

https://www.kpk.go.id/id/statistik/penindakan/109$\underline{\text { statistik }}$

Although the statistics of corruption cases from 2019 to May 2021 have decreased, corruption cases in Indonesia need serious handling from law enforcement 
and related institutions. However, to maximize every program or policy from the government, it requires support and involvement from various levels of society including Non-Governmental Organizations, Community Organizations, and society in general. It is clearly stated in Law no. 31 of 1999 article 41 explains that every citizen of a country must support the performance of the KPK in efforts to prevent corruption. Where the community has the right to find out, obtain and provide information when there is corruption. In addition, it also has the authority to obtain services to find information regarding these assumptions, has the right to express opinions to law enforcement officials, and has the authority to obtain security from state law.

The active role of the community in supervising the crime of corruption includes civil society. This civil society is a citizen who obeys the values and norms used in the community. In addition, civil society is inseparable from the state, both in economic and political activities. Civil society is a society that contributes to political activities. So it can be said that Non-Governmental Organizations, Community Organizations or society in general are civil society, because they can contribute to efforts to monitor and prevent corruption. Therefore, it is important to build the character of Indonesian citizens to form civil society to protect the Indonesian nation from various threats of globalization. The cultivation of community character is guided by the values contained in the precepts of Pancasila, such as the habituation of anticorruption culture that needs to be instilled in the Indonesian people through various means, either education, coaching or other socialization.

Non-Governmental Organizations have a strategic position in the supervision, prevention and eradication of corruption, as clearly stated in Law no. 8 of 1985 , CSOs and NGOs are forums for expressing public opinions and thoughts, and have a role in increasing active community participation in national development. It can be seen that various anti-corruption institutions have been formed in the community, including Indonesia Corruption Watch (ICW), Government Watch (GOWA), Civil Professional Society (MPM) and other anti-corruption institutions. This proves that there is public concern for efforts to prevent corruption, as well as a place to exercise control over the government. Non-Governmental Organizations (NGOs) have a function as control, where NGOs are community empowerment, balancing power and intermediary institutions. In addition, NonGovernmental Organizations (NGOs) have a legal basis, namely Law no. 8 of 1985 concerning Community Organizations and every NGO has legality that is approved by the government.

Therefore, based on the background that has been presented above, the author's attention is drawn to study and conduct research on the Role of Non-Governmental Organizations (NGOs) as Civil Society in the
Supervision of Corruption. With the problem formulation:

1) What is the legal basis for Non-Governmental Organizations (NGOs) in efforts to control corruption in Indonesia?

2) What is the form of participation of NonGovernmental Organizations (NGOs) as civil society in efforts to control corruption in Indonesia?

\section{METHOD}

To answer research problems, researchers used data sources obtained through library research. Literature research does not require researchers to go out into the field to conduct research but uses the data needed in research obtained from various documents or other library sources. According to Zed (2014) literature study is library research that not only prepares a research framework but also utilizes documents or sources in the library in obtaining research data. In conducting this research, the researcher examines various legal sources such as laws and regulations, government regulations, jurisprudence, journals, and other sources related to the problem to be studied.

\section{RESULT AND DISCUSSION}

Corruption is an act of deviant behavior, in other words, corruption is an act that is not by social norms in society. Acts of corruption are not far from people's lives, someone who commits acts of corruption has a nature that is always selfish. If you look at the Klitgaard theory developed by [1] [2](2005), it is explained that corruption is the deviation of the behavior of a person who has a position for the benefit of himself or his group, as well as behavior that violates the rules that regulate personal behavior in the sense of political behavior. Klitgaard's theory is also often referred to as the CDMA theory, in which corruption can occur due to unaccountable power and monopoly factors. If the term CDMA theory is described, it is as follows:

Corruption $=$ Directionary + Monopoly - Accountability $(\mathrm{CDMA})$

Klitgaard's theory explains that corruption is a monopoly by a leader (monopoly of power) which is supported by the power it has (discretion of official) and there is no good enough control (minus accountability) that encourages corrupt behavior. Furthermore, there was a change in the government system which was initially centralized to regional autonomy which caused a shift in corruption actions, where previously corruption only occurred or was carried out at the central government level, now it has penetrated regional governments, corruption has occurred. So this is in line with Klitgaard's theory that acts of corruption follow power. (Waluyo. 2014)

In line with Klitgaard's theory, Breaking argues that acts of corruption in the context of administrative 
corruption or bureaucratic corruption, petty corruption, and giving gifts or bribes. Where administrative or bureaucratic corruption is the provision of illegal money received by public officials in [1] the context of implementing policies, rules, and laws. Johnson explained that corruption is an abuse of position or role for self-interest. So if you look at this understanding, several components can be called acts of corruption including public (public), benefits (benefits), abuse (abuse), and private (private). Jeremy Pope argues that corruption is the abuse of power for its own sake. Corruption is the behavior of public officials who enrich themselves by violating the law. (Handoyo. 2013)

It is also explained in Law no. 31 of 1999 jo. Law No. 20 of 2001 to be exact, Article 2 explains that a person who disobeys the law and enriches himself will cause a loss to the state, then he will be sentenced to life or imprisonment for 4 years and a maximum of 20 years and a fine of 200 million to 1 billion. It can be concluded from these articles that corruption is categorized into 30 types of corruption. It is explained in detail in these articles regarding acts that can be subject to criminal penalties due to acts of corruption. The 30 types of acts of corruption can be categorized, namely acts of bribery, gratification, harming state money, embezzlement of positions, embezzlement of procurement of goods, extortion, and fraudulent acts. (Ardisasmita. 2006)

Legal Basis for Non-Governmental Organizations in Efforts to Control Corruption in Indonesia

Public participation in the supervision, prevention, and eradication of corruption has been regulated in Law no. 31 of 1999 article 41 explains that every citizen of a country must support the performance of the KPK in efforts to prevent corruption. The public has the right to find out, obtain and provide information when there is corruption. And has the authority to obtain services to find information about these assumptions, has the right to express opinions to law enforcement officials, and has the authority to obtain security from state law. Then more specifically, it is found in Government Regulation No. 71 of 2000 concerning Procedures for Implementing Community Participation and Awarding in the Prevention and Eradication of Corruption, it is stated that the role of the individual community, Community Organizations, and Non-Governmental Organizations in preventing and eradicating corruption.

The participation of Community Organizations and Non-Governmental Organizations in the supervision, prevention, and eradication of corruption has been regulated in The United Nations Convention Against Corruption (UNCAC) 2003 article 13 which explains that every country must take appropriate action by applicable law, improve community participation individually and in groups such as Community Organizations, Non-Governmental Organizations and other institutions outside government institutions. The legal basis and the position of Non-Governmental Organizations and Community Organizations in the supervision, prevention, and eradication of corruption in Indonesia are explained as follows:

a) The Constitution of the Republic of Indonesia 1945 article 28 E paragraph (3) and the Constitution of the Republic of Indonesia 1945 article 21 paragraph (1) explains that every community has the right to freedom of association, assembly, and expression. So that Non-Governmental Organizations have the right to participate in the preparation and supervision of the budget.

b) Government Regulation No. 71 of 2000 concerning Procedures for Implementing Community Participation and Awarding in the Prevention and Eradication of Corruption, explains that NonGovernmental Organizations have the right to seek, obtain and provide information in the event of corruption. So those Non-Governmental Organizations that have contributed to the prevention and eradication of corruption are entitled to an award.

c) Government Regulation No. 68 of 1999 concerning Procedures for Implementing Community Participation, explains that the community or NonGovernmental Organizations are expected to participate in realizing a clean and free implementation of corruption, collusion and nepotism by complying with applicable laws and social norms.

d) Law No. 20 of 2001 concerning the Eradication of Corruption, that the public is expected to participate in preventing corruption. So the government will give an award to those who have participated in corruption efforts.

e) Law No. 28 of 1999 concerning the Implementation of a Clean and Free State of Corruption, Collusion, and Nepotism, that the community has a responsibility to realize a clean and free state administration from corruption, collusion, and nepotism.

f) Law No. 31 of 1999 article 41 explains that every citizen of a country must support the performance of the KPK in efforts to prevent corruption.

g) Law No. 25 of 2004 concerning the National Development Planning System, that in the design and development of National it requires community involvement so that it is expected to provide input both orally and in writing in a discussion of draft regional regulations.

h) Law No. 17 of 2013 concerning Community Organizations, that community organizations are a means of channeling community aspirations.

i) TAP MPR No. XI/MPR-RI/1999 concerning Policy Directions for the Prevention and Eradication of Corruption, Collusion, and Nepotism, that public participation in social control in the life of the nation and state. So Non-Governmental Organizations can participate in efforts to monitor corruption, collusion, and nepotism. 
j) Instruction of the Minister of Home Affairs No. 8 of 1990 concerning the Development of NonGovernmental Organizations, that NonGovernmental Organizations are a forum for the community to participate in efforts to organize a clean and free of corruption State.

Judging from the explanation, the legal basis for Non-Governmental Organizations in efforts to monitor, prevent and eradicate corruption in Indonesia can be said to be quite strong. The community can follow several things to be able to contribute effectively including:

a) Abstinence from being involved in corruption, by having the determination not to be involved in corruption, the community can effectively participate in preventing corruption. However, for this, other supports are needed such as public understanding of corruption, types of corruption, and so on.

b) Practicing to integrate, integration here is intended as harmony between one's speech and behavior to be determined not to commit a criminal act of corruption. Integration can also be said of someone's honesty in everyday life.

c) Inviting people around us to participate in preventing corruption, we cannot carry out anticorruption behavior alone. So as someone who lives in groups, he must also invite other people in the surrounding environment to behave anti-corruption such as those closest to family, friends, friends, and other people in the environment around the house.

d) Choosing a role, the public can choose a role in the efforts to monitor and prevent corruption. Considering that the KPK has various strategies in efforts to monitor and prevent corruption. Not only using repressive methods, but the KPK also conducts system studies as well as campaigns and education. Therefore, the community can choose through what means to carry out efforts to monitor and prevent corruption. Some of the roles that the community can choose include: participating in repressive strategies, participating in system improvement, participating in campaigns or education, or reporting if they know of the corruption in the surrounding environment. (Corruption Eradication Commission. 2015)

Forms of Participation of Non-Governmental Organizations (NGOs) as Civil Society in Efforts to Control Corruption in Indonesia

Indonesia is a country that has abundant natural resources in terms of agriculture, mining, oil \& gas, and others. In addition to the natural wealth owned by the Nation, there is also cultural diversity ranging from differences in ethnicity, race, values and norms from each region of Indonesia which makes this nation a multicultural nation. However, it is not enough to say that Indonesia is a prosperous country with its natural wealth. One of the causes and problems in Indonesia today is corruption. According to the survey results from the Central Statistics Agency, the poverty rate has increased in the survey results in September 2020 compared to 2019. In 2019 the poverty rate in Indonesia reached $24.79 \%$, while in 2020 the poverty rate in Indonesia reached $27.55 \%$. This means that in September 2020 it reached 27.55 million people, the number of poor people in Indonesia, which if you look at the statistics from 2010 to 2019 it shows a decline.

Various factors have caused an increase in the poor population in Indonesia, one of which is that in 2020 Indonesia was hit by a pandemic that affected the economic life of the community. However, the pandemic problem is not a protracted problem, considering that the Indonesian government has a policy of providing social assistance in the form of money and basic necessities for the community as well as internet assistance for students. However, there are individuals who take advantage of situations like this, which at the end of 2020 were exposed to cases of corruption in social assistance. So no matter how good the policies issued by the government and no matter how rich a country is, it will not make the country a prosperous country if corruption cases are still a worrying problem.

The participation of all levels of society, including State Apparatus Institutions, Non-Governmental Organizations, Community Organizations, and society in general, in the supervision, prevention, and eradication of corruption is required. As described in Law no. 31 of 1999 article 41 explains that every citizen of a country must support the performance of the Corruption Eradication Commission in efforts to prevent corruption. The active role of the community in supervising the crime of corruption includes civil society. Civil society is a citizen who obeys the values and norms used in the community. In addition, civil society is inseparable from the state, both in economic and political activities. Basically, civil society is a society that contributes to political activities. Strengthened by the opinion of AS Hikam (as in Nuriani Latuconsina [2]. 2013) of the view that civil society includes social life (between the family and the state) which is organized and has characteristics such as volunteerism, self-sufficiency \& self-sufficiency, has links with legal norms and values that are adhered to by citizens. country.

It can be concluded that Non-Governmental Organizations are part of civil society, judging from the contribution of Non-Governmental Organizations in national development. Therefore, it is important to build the character of Indonesian citizens to become a civil society to protect the Indonesian nation from various threats of globalization. The cultivation of community character is guided by the values contained in the Pancasila precepts such as the habituation of an anti-corruption culture that needs to be instilled in the Indonesian people through various means, either education, coaching, or other socialization activities. 
Considering that Non-Governmental Organizations can act as a counterweight, community empowerment, and as an intermediary institution that has an active role in preventing, controlling, and handling various problems that occur in society or government.

Anti-Corruption Community Organizations or NonGovernmental Organizations in Indonesia, including:

a) Indonesia Corruption Watch (ICW)

Indonesia Corruption Watch (ICW) was formed during the reform era in 1998, led by several YLBHI activists, with the belief that corruption must be eradicated because it has impoverished and undermined poverty. ICW supports governance that is democratic, free from corruption, with economic, social and gender justice. In addition, ICW believes that the people in an organized manner can monitor and control the government. ICW oversees several regulations that support the eradication of corruption in Indonesia, including the KPK Law, the Witness and Victim Protection Law, the Public Information Disclosure Act, the Election Law, the Money Laundering Law, and the Education System Law. National. The Vision and Mission of Indonesia Corruption Watch (ICW), are as follows:

Vision
Strengthening the bargaining position of the people to
control the state and participate in decisions to realize
democratic governance, free from corruption,
economic, social, and gender justice.
Mission
Is to empower the people in:

1) Fight for the realization of a political, legal, economic, and bureaucratic system that is free from corruption and based on social and gender justice.

2) Strengthen people's participation in the policymaking and monitoring process.

\section{b) Transparency International Indonesia (TII)}

Transparency International Indonesia (TII) is one of the chapters of Transparency International, a nongovernmental organization that promotes transparency and accountability of state institutions, political parties, businesses, and civil society. Transparency International Indonesia (TII) combines the work of think tanks and social movements. As a think-tank, Transparency International Indonesia (TII) monitors policies, encourages reform of law enforcement agencies, and consistently measures corruption through the Corruption Perception Index, the Crinis Project, and other research publications. As a social movement, Transparency International Indonesia (TII) is active in various collaborations with anti-corruption movements in Indonesia.

\section{c) Anti-Corruption Community Solidarity}

Anti-Corruption Community Solidarity is an independent civil society organization that was founded in 1999, by activists from non-governmental organizations, academics, community leaders, and the government. The Anti-Corruption Community Solidarity aims to create transparency and eradicate corruption, collusion, and nepotism practices in the administration of Acehnese society. The Vision and Mission of Anti-Corruption Community Solidarity are as follows:

\section{Vision}

Anti-Corruption Community Solidarity is the establishment of a strong and influential social movement to free Aceh from corruption, collusion, and nepotism. Mission

Anti-Corruption Community Solidarity is: Strengthening people's participation in the formation of an anti-corruption movement, strengthening the capacity of the SAMAK organization to become a strong and effective organization, and encouraging policy changes that are transparent and free from corruption, collusion, and nepotism.

\section{CONCLUSION}

Based on the results of research and studies that have been carried out in this study, it can be concluded that Non-Governmental Organizations have an important role in the creation of a prosperous country by participating in efforts to monitor, prevent and supervise corruption. Therefore, Non-Governmental Organizations are very strategic to support the programs or policies of the Corruption Eradication Commission in monitoring, preventing, and eradicating corruption. Considering that Non-Governmental Organizations can act as a counterweight, community empowerment, and as an intermediary institution that has an active role in preventing, controlling, and handling various problems that occur in society or government.

Non-Governmental Organizations are part of civil society, looking at the contributions of NonGovernmental Organizations in national development. as previously described there are several legal foundations regarding Non-Governmental Organizations as in Law no. 8 of 1985 , Ormas is a forum for expressing public opinion and thoughts, and has a role in increasing active community participation in national development. It is clarified in the Instruction of the Minister of Home Affairs No. 8 of 1990 concerning the Development of Non-Governmental Organizations, that Non-Governmental Organizations are a forum for the community to participate in efforts to organize a clean and free of corruption State.

\section{ACKNOWLEDGMENTS}

Praise and gratitude to God Almighty for His mercy and grace so that this paper can be completed on time, not forgetting to the Prophet Muhammad SAW. As well as to the lecturers who always provide support and guidance to the author, thank you to both parents who always provide support and prayers. Hopefully, the 
support from all parties can provide benefits for the readers of this paper.

\section{REFERENCES}

[1] R. Klitgaard, Eradicating Corruption, Jakarta: Indonesia Torch Foundation, 2005.

[2] Sumarni, "The Role of Non-Governmental Organization in the Prevention, Control and Handling of Corruption Cases in Samarinda City," eJournal of Sociology, Vols. Volume 3, Number 2, no. ejournal.sos.fisip-umnul.org, pp. 111-123, 2015.

[3] Waluyo, "Optimization of Corruption Eradication in Indonesia," Juridical Journal, vol. Vol. 1 No. 2, p. 169 - 182, December 2014.

[4] N. Latuconsina, "Development of Democracy and Civil Society in Indonesia," Populists, vol. Volume 7, 2013.

[5] C. E. Commission, "Corruption Eradication Commission," Corruption Eradication Commission, 8 May 2021. [Online]. Available: https://www.kpk.go.id/id/statistik/penindakan/109statistik . [Accessed 9 April 2021].

[6] C. E. Commission, Capita Selecta and the Burden of Social Costs of Corruption, Jakarta: Directorate of Education and Community Services, Deputy for Prevention, Corruption Eradication Commission, 2015.

[7] I. C. W. (ICW), "Who Is ICW," Indonesia Corruption Watch (ICW), 2017. [Online]. Available: https://www.antikorupsi.org/id/page/siapa-icw. [Accessed 8 April 2021].

[8] K. W. L. Johnny A, "Partticipation of Community Organizations in the Eradication of Corruption in Indonesia," Lex Et Societatis, vol. Vol. VI/No.4, 2018.

[9] M. Zed, Library Research Methods, Jakarta: Indonesia Torch Foundation, 2014.

[10] M. Ardisasmita, "Definition of Corruption According to Legal Perspective and EAnnouncement for Better Governance," in RI Corruption Eradication Commission, Jakarta, 2006.

[11] Handoyo, Anti-Corruption Education, Semarang: Ombak (IKAPI Member), 2013.

\section{Government Documents}

1) Government Regulation No. 71 of 2000 concerning
Procedures for Implementing Community Participation and Awarding in the Prevention and Eradication of Corruption

2) Government Regulation No. 68 of 1999 concerning Procedures for Implementation of Community Participation

3) Instruction of the Minister of Home Affairs No. 8 of 1990 concerning the Development of NonGovernmental Organizations

4) Law No. 31 of 1999 concerning the Eradication of Corruption Crimes

5) Law No. 20 of 2001 concerning the Eradication of Corruption

6) Law No. 28 of 1999 concerning the Implementation of a Clean and Free State of Corruption, Collusion, and Nepotism

7) Law No. 25 of 2004 concerning the National Development Planning System

8) Law No. 17 of 2013 concerning Community Organizations

9) Law No. 28 of 1999 concerning the Implementation of a Clean and Free State of Corruption, Collusion, and Nepotism

10) TAP MPR No. XI/MPR-RI/1999 on Policy Directions for the Prevention and Eradication of Corruption 